\title{
Prevalence of Refractive Errors and their Underlying Factors amongst students of Islam Medical College, Sialkot
}

\author{
FARWA TAHIR ${ }^{1}$, IFRA TAHIR ${ }^{1}$, FATAWAL TAHIR ${ }^{2}$, MUHAMMAD TARIQ BANGASH ${ }^{3}$, ROZINA SHAHADAT KHAN ${ }^{4}$ \\ 1/slam Medical College Sialkot. \\ ${ }^{2} \mathrm{CMH}$ Combined Military Hospital Sialkot \\ 3/slam Medical College, Sialkot/ Betsi Cadwaladr University Health Board, Whales NHS, UK. \\ ${ }^{4} D G$ Khan Medical College DG khan \\ Correspondence to Dr Farwa Tahir, Email: drfarwatahir8@gmail.com Cell : 03009724141
}

\begin{abstract}
Aim: To determine prevalence of refractive errors \& underlying factors amongst students of Islam Medical College, Sialkot.

Study design: Descriptive cross sectional study.

Place and duration: At Islam Medical College, Sialkot, from August to October 2019

Methods: Our study was descriptive cross sectional study, evaluated by the formulation of a detailed questionnaire, which was answered by all respondents. One hundred and fifty students doing MBBS were selected by simple random sampling. The data was analysed using IBM SPSS.

Results: It was found out that refractive errors were present in 93 out of $150(62 \%)$ medical students of Islam medical college. Prevalence of myopia (59.3\%) was found to be the commonest type of refractive error ( $95.7 \%$ of those having refractive errors). On the same hand the possible underlying factors for causation of refractive errors were mainly found to be present in majority of the people having refractive errors. The greater number of the people responded about their feeling better after wearing spectacles.

Conclusion: Arising from our this study; the significance of the prevalence of refractive errors especially myopia, the presence of possible underlying factors and the positive effect of wearing the spectacles, in the students of Islam Medical College Sialkot, has been highlighted.

Keywords: Ametropes, Emmetropes, Medical students, prevalence, refractive errors, underlying factors,
\end{abstract}

\section{INTRODUCTION}

The normal state of the vision is the one in which the eye does not need any corrective lenses and at which the refractive power of the cornea and the axial length of the eye ball are so well balanced out, that the image of an object gets focused on the retina. This perfect state is called as emmetropia. While on the other hand, the state of refractive error is called ametropia. It is known to be caused by a malformation of the eyeball causing the disturbance of the balance of refractive power of the cornea, lens and the axial length that in turn leads to vision disorders where eye is unable to correctly focus the images of objects on the retina. Ametropia includes myopia (short or near-sightedness), hypermetropia or hyperopia (long or far-sightedness) and astigmatism.

World health organization (WHO) defined refractive error as following, "A refractive error is disorder of eyes that is very common. It occurs when the eye is not able to focus on targets. As a result there is blurring of vision which is sometimes so severe that it can cause visual impairment $1 "$."

According to World Health Organisation (WHO) it has been estimated that 153 million people worldwide have visual impairment because of the uncorrected refractive errors ${ }^{1}$. Refractive error is havoc to public health and it also cause heavy financial load on the society ${ }^{2}$. Refractive errors that are not corrected by any means like; aid by spectacles, contact lenses or correction by surgeries, create a notably significant impact on learning and academic success ${ }^{3}$. As medicals students are considered to spend maximum time in desk work, exams and assignments etc, a high prevalence of refractive errors were seen among them, while they were unaware about it ${ }^{4}$.

Although there are no proven facts about the exact factors that results in the causation of the refractive errors, however a few possible causative factors like; long time spent doing near work, excess of usage of digital gadgets or inappropriate light while working etc are still considered to be as the culprits. As yet, it is an established fact that refractive errors cannot be prevented but they can only be timely diagnosed and treated. If corrected in time it results in least causation of various deterioration on personal,

Received on 29-04-2021

Accepted on 19-09-2021 social and professional levels. While the possible so-thought causative factors can be avoided or lessened to improve the prognosis of the correction or slow down the slumping of the vision

With this background and considering medical students as our population regarding this important issue we decided to formulate this study to highlight the prevalence of refractive errors and their underlying causative factors that in turn summit the importance of corrected refractive errors that too majorly using the spectacles as they remain the most safe easy and easily available aid. While this timely correction can only made possible by the timely check-up and optimized follow-ups.

\section{PATIENTS AND METHODS}

A detailed questionnaire proforma was randomly distributed to medical students of Islam Medical College, Sialkot, to study the prevalence and underlying factors of refractive errors after permission from IRB. The answers of the students were tabulated and analyzed. The number of students in the study were 150, 45 males and 105 females. The presence of refractive errors like myopia, hypermetropia and astigmatism were noted by asking them relevant questions. Various factors that could contribute towards refractive errors including time spent for close work, watching television, using mobiles and other gadgets, distances for reading and watching television were also studied. The genetic factors (family history), type of light used, other eye conditions and co morbidity in the respondents were also asked for and then evaluated. The rate of progress of refractive errors and options for correction of refractive error were noted too by asking appropriate questions in the designed questionnaire. Special permission from the college authorities were taken before distributing the questionnaires. Collaboration between students and the teachers allocated to them, was established to facilitate the process of distribution and filling of the proformas. Similarly strict privacy and confidentiality and care about the academic timings was ensured at all levels till the completion of the results.

\section{RESULTS}

Statistical analysis was carried out by using SPSS. Figures consist of different tables. 
Table 1 shows us the demographic distribution of the respondents, which include 45 males (30\%) and 105 females $(70 \%)$ out of the total number of respondents of 150 . The age distribution of the respondents was ranging from 17-26 years, with a mean age of 21 years. The maximum number of respondents are present within 21-22years of age (i.e. $30.7 \%$ ).

Table 2 shows that 93 out of $150(62 \%)$ of the students were having refractive errors, while 57 students out of 150 (38\%) were emmetropes. Prevalence of myopia amongst the respondents was $59.3 \%$ (short-sightedness) which is the most commonly occurring refractive error, prevalence of hypermetropia was $0.7 \%$ (longsightedness) and prevalence of astigmatism was $54.7 \%$.

Table 3 shows the results of various questions evaluated for the respondents with refractive errors (ametropes), i.e. 93 students $(n=93)$. The results for how often the respondents (ametropes) get their eye sight checked, is as follows, $19.4 \%$ get their eye sight checked every 6 months, $28 \%$ get their eye sight checked annually, $51.6 \%$ get their eye sight checked only when they feel their prescription is getting changed (unclear vision with the lens of the present glasses), while $1.1 \%$ get their eye sight never checked. The results of rate of progress of refractive errors amongst the ametropes is as follows. Changing every 6 months $11.8 \%$, changing every year $17.2 \%$, changing after more than 1 year $50.5 \%$, while $20.4 \% \%$ have a constant unchanged prescription for the power of their spectacles. The results of the symptoms patients (ametropes) had before glasses is as follows. Asymptomatic $8.6 \%$, blurring of vision $37.6 \%$, headache $19.4 \%$, dizziness $2.2 \%$, eye strain $8.6 \%$, while $23.7 \%$ had more than one symptoms. The results of the problems still experienced by the ametropes with glasses is as follows. People not getting used to glasses $16.1 \%$, blurring of the vision $8.0 \%$, headache $11.5 \%$, dizziness $1.1 \%$, eye strain $5.7 \%$, more than one symptom $4.6 \%$, while the highest percentage i.e. $52.9 \%$ said that it gets better when wearing glasses. The time spent by ametropes for close work as follows: $37.6 \%$ spend $2-5$ hours, $41.9 \%$ spend $5-10$ hours, $10.8 \%$ spend 10-12 hours while $9.7 \%$ spend more than 12 hours. The distance at which the ametropes read: Close to face at $33 \mathrm{cms} 23.7 \%$, $62.4 \%$ read at half of arm's length while $14 \%$ read at full arm length. The type of light used by the ametropes for close work. Fluorescent light $81.7 \%$ while $18.3 \%$ use reading lamp light. The time spent by ametropes for watching television in a day. $64.5 \%$ watch television upto 2 hours, $18.3 \%$ upto 5 hours, $5.4 \%$ for more than 5 hours, $1.1 \%$ upto 10 hours and $10.8 \% \%$ do not watch any television. The distance for watching television by ametropes. $18.4 \%$ watch it from less than 2 meters, $40.2 \%$ from it from $2-3$ meters, $21.8 \%$ from $3-4$ meters and $19.5 \%$ watch it from more than 4 meters. The time spent by ametropes on mobile gadgets per day. Upto 5 hours by $64.5 \%, 5-10$ hours by $17.2 \%$ and $18.3 \%$ spend upto 10-12 hours. The co-existence of any other eye condition amongst the ametropes which included red eyes in $10.8 \%$, strain in $4.3 \%$, pain in $7.5 \%$, itching in $5.4 \%$, halos $1.1 \%$, $4.3 \%$ had non describable or other issues while $66.7 \%$ of the ametropes had no other eye condition present. The presence of co-morbidity in ametropes as follows. $96.8 \%$ had no co-morbidity while only $3.2 \%$ reported co-morbidity. Family history shows that, $81.7 \%$ of the ametropes family members use spectacles too, while $18.3 \%$ have no family history. The results of the ametropes who considered treatment for the removal of glasses by refractive surgery is, $35.5 \%$ considered having the corrective treatment, while $64.5 \%$ did not consider it.

Demographic distribution of the respondents
\begin{tabular}{|l|l|}
\hline Groups & \multicolumn{1}{c|}{$\mathbf{n = 1 5 0}$} \\
\hline \multirow{4}{*}{ Age (Years) } & $17-18(16 \%)$ \\
\cline { 2 - 2 } & $19-20(40 \%)$ \\
\cline { 2 - 2 } & $21-22(30.7 \%)$ \\
\cline { 2 - 2 } & $23-24(12.7 \%)$ \\
\cline { 2 - 2 } & $25-26(0.7 \%)$ \\
\hline Gender Distribution & Male $(30 \%)$ \\
\cline { 2 - 2 } & Female $(70 \%)$ \\
\hline
\end{tabular}

Prevalence of refractive errors and types of refractive errors at Khawaja Muhammad Safdar Medical College, Sialkot.

\begin{tabular}{|l|c|}
\hline $\begin{array}{l}\text { Prevalence of types of } \\
\text { Refractive Errors. }\end{array}$ & Response in percentages. $\mathbf{n = 1 5 0}$ \\
\hline Refractive Errors present & $62 \%$ \\
\hline Emetropes & $38 \%$ \\
\hline Myopia & $59.3 \%$ \\
\hline Hypermetropia & $0.7 \%$ \\
\hline Astigmatism & $54.7 \%$ \\
\hline
\end{tabular}

\section{RESULTS}

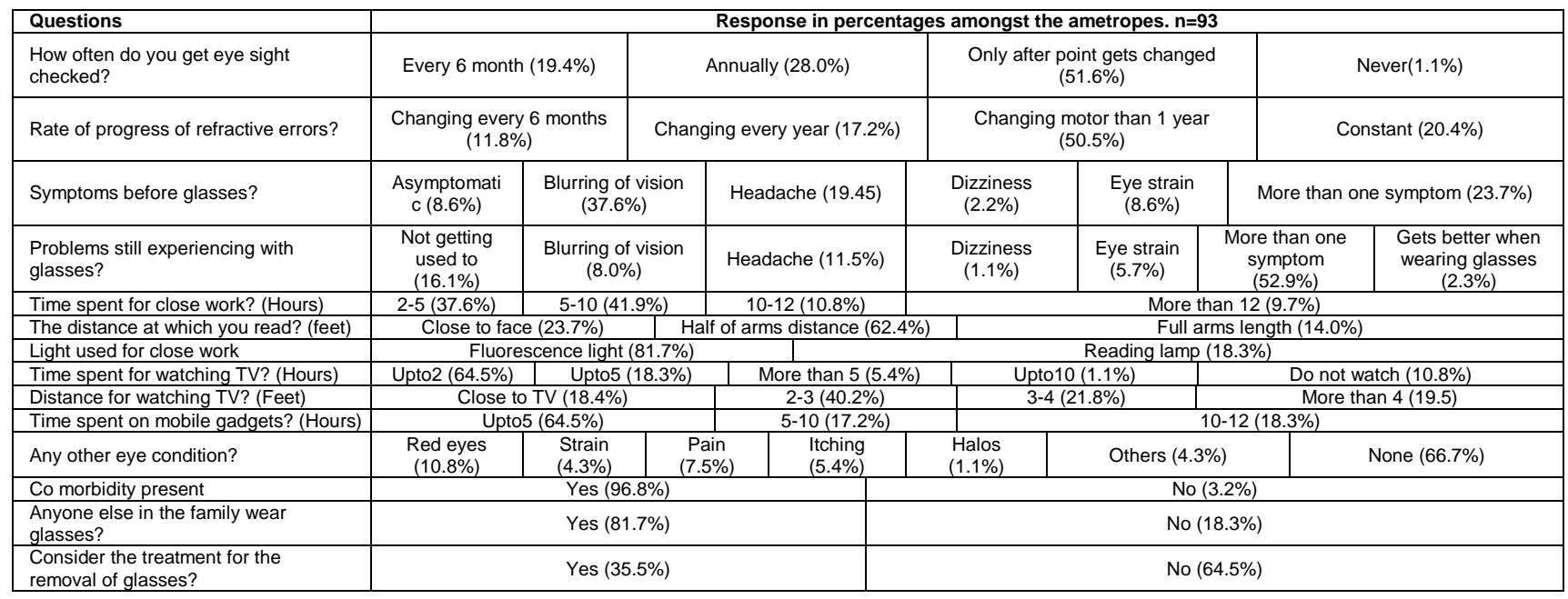

\section{DISCUSSION}

The most common cases, appearing as cases of eye disorder, are those of refractive errors. The common types of refractive error that too on the list are; near-sightedness, farsightedness, astigmatism, and presbyopia ${ }^{5}$. In near-sightedness far away objects cannot be focused and are seen as blurry. In case of far-sightedness and presbyopia close objects cannot be focused and are seen as blurry. Astigmatism causes objects to appear stretched out or blurry ${ }^{5}$. Near-sightedness is due to the length of the eyeball being too long. In far-sightedness the eyeball is too short. In astigmatism the cornea being the wrong shape. Where as 
in presbyopia aging of the lens of the eye occurs such that it cannot change shape sufficiently to focus the imagine on the retina ${ }^{5}$. Some refractive errors occur more often among those whose parents also have refractive errors ${ }^{5}$. Diagnosis of the refractive errors can only be done by eye examination ${ }^{5}$. Refractive errors are corrected with various methods like eyeglasses, contact lenses, or surgery ${ }^{5}$. Eyeglasses are the easiest and safest method of correction ${ }^{5}$. Contact lenses can although provide a wider field of vision but they are associated with a risk of infection ${ }^{5}$. Refractive surgery permanently changes the shape of the cornea ${ }^{5}$.

Globally the number of people with refractive errors has been estimated as one to two billion ${ }^{6}$. Rates vary between regions of the world with about $25 \%$ of Europeans and $80 \%$ of Asians affected $^{6}$. Near-sightedness is the most common disorder ${ }^{7}$. Rates among adults are between $15-49 \%$ while rates among children are between $1.2-42 \%^{8}$. Far-sightedness more commonly affects young children and the elderly ${ }^{9,10}$. Presbyopia affects most people over the age of $35^{5}$. The number of people with refractive errors that have not been corrected was estimated at 660 million (10 per 100 people) in $2013^{11}$. Of these 9.5 million were blind due to the refractive error ${ }^{11}$. It is one of the most common causes of vision loss along with cataracts, macular degeneration, and vitamin $A$ deficiency ${ }^{12}$. There is evidence to suggest genetic predilection for refractive error. Individuals that have parents with certain refractive errors are more likely to have similar refractive errors ${ }^{5}$. The Online Mendelian Inheritance in Man (OMIM) database has listed 261 genetic disorders in which myopia is one of the symptoms ${ }^{13}$. Many genes that have been associated with refractive error are clustered into common biological networks involved in connective tissue growth and extracellular matrix organization ${ }^{14}$. Although a large number of chromosomal localisations have been associated with myopia (MYP1-MYP17), few specific genes have been identified ${ }^{13}$. In studies of the genetic predisposition of refractive error, there is a correlation between environmental factors and the risk of developing myopia ${ }^{16}$. Myopia has been observed in individuals with visually intensive occupations ${ }^{15}$. Reading has also been found to be a predictor of myopia in children. It has been reported that children with myopia spent significantly more time reading than non-myopic children who spent more time playing outdoors ${ }^{15}$. Socioeconomic status and higher levels of education have also been reported to be a risk factor for myopia.

Our study was conducted amongst the medical students, who are relatively more exposed to near work. The overall occurrence of refractive errors in our study was 150(62\%), with myopia being the most common type with prevalence of $59.3 \%$ (97.5\% of ametropes, excluding emetropes). The data matches other similar studies in medical students of Pakistan $(58 \%)^{17}$, Norway $93(50 \%)^{18}$ and Copenhagen $(50.3 \%)^{19}$. Yet, Lower prevalence of refractive errors has been reported in Turkey $(32.9 \%)^{20}$. The prevalence of refractive errors reported in our study is much lower than that reported in Taiwan $(93 \%)^{21}$, Singapore $(90 \%)^{22}$ and China $(71 \%)^{23}$ where the prevalence of refractive errors is much higher than that observed in our study.

The higher rate of refractive errors, especially myopia, in medical students was possibly due to many contributing factors such as, the high level of educational achievement ${ }^{24}$, above average intelligence ${ }^{25}$, long and exhaustive study schedule and prolonged near work ${ }^{26}$ as compared to majority of the other nonmedical students. Medical students are a group of young adults who spend prolonged periods on reading and close work. With their rigorous study schedule that spans an average of 5 to 6 years, they have been reported to be at high risk for myopia ${ }^{18,22,23,26}$. This is evident from our study conducted amongst the medical students.

The precise pathogenesis of myopisation of ocular refractive machinery by near work is yet to be fully established and understood. According to a recent theory, the blurred retinal image that occurs during prolonged near work leads to myopia. This blurring of retinal images stimulates the biochemical and chemical changes in sclera and choroid that lead to axial elongation ${ }^{27}$.
WHO started a program "vision 2020", The mission of the VISION 2020 Global Initiative is to remove the main causes of all preventable and treatable blindness as a public health issue by the year 2020 , with the target to achieve vision of $20 / 20$, i.e. $6 / 6$ for everyone by the year 2020. It focuses on every person right to sight, with the aim to reduce the visual disability and blindness ${ }^{28}$ .Eighty percent of the visual impairment in young people between the ages of 12 to 15 years is due to the refractive errors in USA ${ }^{29}$. Prevalence of myopia is greater than hypermetropia and there is an expected rise of myopia patients to 2.6 billion by the year 2020 . This shows that how much important it is have the timely correction of the refractive errors.

\section{CONCLUSION}

The prevalence of refractive errors especially high rate of myopia amongst the medical students of Islam Medical College, having all possible causative factors, contributing in the causations of refractive errors, marked as positive is very much highlighted which becomes better only after interventions like wearing of spectacles .

Conflicts and interests: This study has no conflict of interest to be declared by the authors

\section{REFERENCES}

1. https://www.who.int/features/qa/45/en/

2. Roberts $\mathrm{CB}^{1}$, Hiratsuka Y, Yamada M, Pezzullo ML, Yates K, Takano S, Miyake K, Taylor HR. et al. Economic cost of visual impairment in Japan. Arch Ophthalmol. 2010 Jun;128(6):766-71. doi: 10.1001/archophthalmol.2010.86

3. Megbelayin, E. O.; Asana, U. E.; Nkanga, D. G.; Duke, R. E.; Ibanga, A. A.; Etim, B. A.; Okonkwo, S. N. Refractive errors and spectacle use behavior among medical students in a Nigerian medical school. British Journal of Medicine and Medical Research 2014 Vol.4 No.13 pp.25812589 ref.31

4. Rajdeep P, Patel R. A study of refractive errors on students of Baroda Medical College. IJRRMS 2013;3: 118-19

5. "Facts About Refractive Errors". NEl. October 2010. Archived from the original on 28 July 2016. Retrieved 29 July 2016.

6. Denniston, Alastair; Murray, Philip (2018). Oxford Handbook of Ophthalmology (4 ed.). OUP Oxford. p. 926. ISBN 9780198816751.

7. Foster, PJ; Jiang, Y (February 2014). "Epidemiology of myopia". Eye (London, England). 28 (2): 202

8. doi:10.1038/eye.2013.280. PMC 3930282. PMID 24406412.

9. Pan, CW; Ramamurthy, D; Saw, SM (January 2012). "Worldwide prevalence and risk factors for myopia". Ophthalmic \& Physiological Optics. 32 (1): 3-16. doi:10.1111/j.14751313.2011.00884.x. PMID 22150586.

10. Castagno, VD; Fassa, AG; Carret, ML; Vilela, MA; Meucci, RD (23 December 2014). "Hyperopia: a metaanalysis of prevalence and a review of associated factors among school-aged children". BMC Ophthalmology. 14: 163. doi:10.1186/1471-2415-14-163. PMC 4391667. PMID 25539893.

11. Grosvenor, Theodore (2007). Primary care optometry (5 ed.). St. Louis (Miss.): Butterworth Heinemann, Elsevier. p. 70. ISBN 9780750675758. Archived from the original on 2016-08-15.

12. Global Burden of Disease Study 2013, Collaborators (22 August 2015). "Global, regional, and national incidence, prevalence, and years lived with disability for 301 acute and chronic diseases and injuries in 188 countries, 1990-2013: a systematic analysis for the Global Burden of Disease Study 2013". Lancet. 386(9995): 743-800. doi:10.1016/s0140-6736(15)606924. PMC 4561509. PMID 26063472.

13. Pan, CW; Dirani, M; Cheng, CY; Wong, TY; Saw, SM (March 2015). "The age-specific prevalence of myopia in Asia: a meta-analysis". Optometry and Vision Science. 92 (3): $258-66$. doi:10.1097/opx.0000000000000516. PMID 25611765.

14. Morgan, lan; Kyoko Ohno-Matsui (May 2012). "Myopia". The Lancet 379 (9827): 1739- 1748. doi:10.1016/S0140-6736(12)60272-4. PMID 22559900.

15. Wojciechowski, Robert (April 2011). "Nature and Nurture: the complex genetics of myopia and refractive error". Clin Genet. 79 (4): 301-320. doi:10.1111/j.13990004.2010.01592.x. PMC 3058260. PMID 21155761.

16. Wojcienchowski, Robert (April 2011). "Nature and Nurture: the complex genetics of myopia and refractive error". National Institutes of 
Health. 79 (4): 301-320. doi:10.1111/j.13990004.2010.01592.x. PMC 3058260. PMID 21155761.

17. Barnes, Katherine (February 2013). "Genome-wide meta-analyses of multiancestry cohorts identify multiple new susceptibility loci for refractive error and myopia". Nature Genetics. 45 (3): 314- 8. doi:10.1038/ng.2554. PMC 3740568. PMID 23396134.

18. Chaudhry R, Ali H, Sheikh NH. Frequency and underlying factors of myopia among medical students. Biomedica2011;27: 154-160.

19. Midelfart A, Aamo B, Sjohaug KA, Dysthe BE. Myopia among medical students in Norway. Acta Ophthalmol (Copenh). 1992;70:317-322.

20. Fledelius HC. Myopia profile in Copenhagen medical students 199698. Refractive stability over a century is suggested. Acta Ophthalmo Scand. 2000;78:501-505.

21. Onal S, Toker E, Akingol Z, Arslan G, Ertan S, Turan C, et al. Refractive Errors of Medical Students in Turkey: One Year Follow-Up of refraction and Biometry. Optm Vis Sci. 2007;84:175-180. (20

22. Lin LL, Shih YF, Lee YC, Hung PT, Hou PK. Changes in ocular refraction and its components among medical students-a 5-year longitudinal study. Optometry and Vision Science 1996;73: 495498.(21

23. Woo WW, Lim KA, Yang H, Lim XY, Liew F, Lee YS et al. Refractive errors in medical students in Singapore. Singapore Medical Journal 2004;45: 470-474.(22

24. Wu Y, Yi H, Liu W, Jia H, Eshita Y, Wang S et al. Risk factors for myopia in Inner Mongolia medical students in China. Open Journal of Epidemiology.2012;2: 83-89.(23
25. Saw SM, Katz J, Schein OD, Chew SJ, Chan TK. Epidemiology of myopia. Epidemiol Rev. 1996;18:175-187.(24

26. Akrami A, Bakmohammad N, Seyedabadi M, Nabipour I, Mirzaei Z, Farrokhi S, et al. The association between schoolchildren intelligence and refractive error. European Review for Med Pharm Sci. 2012;16;908-912.(25

27. Gopalakrishnan S, Prakash MVS, Kumar Jha KR. A Study of Refractive Errors among Medical students in AIMST University, Malaysia. Indian Med J. 2001;105:365-374.(218m

28. Diether S, Gekeler F, Schaeffel F. Changes in contrast sensitivity induced by defocus and their possible relations to emmetropization in the chicken. Invest Ophthalmol VisSci. 2001;42:302307

29. Gilbert $\mathrm{C}^{1}$, Foster A. Childhood blindness in the context of VISION 2020--the right to sight. Bull World Health Organ. 2001;79(3):227-32. Epub 2003 Jul 7.(28)

30. Williams $\mathrm{KM}^{1}$, Verhoeven VJ, Cumberland P, Bertelsen G, Wolfram C, Buitendijk GH, Hofman A, van Duijn CM, Vingerling JR, Kuijpers RW, Höhn R, Mirshahi A, Khawaja AP, Luben RN, Erke MG, von Hanno T, Mahroo O, Hogg R, Gieger C, Cougnard-Grégoire A, Anastasopoulos E, Bron A, Dartigues JF, Korobelnik JF, Creuzot-Garcher C, Topouzis F, Delcourt C, Rahi J, Meitinger T, Fletcher A, Foster PJ, Pfeiffer N, Klaver CC, Hammond CJ. Prevalence of refractive error in Europe: the European Eye Epidemiology (E(3)) Consortium. Eur J Epidemiol. 2015 Apr;30(4):305-15. doi: 10.1007/s10654-015-0010-0. Epub 2015 Mar 18.(29) 